\title{
Lourdes
}

\section{Processioner og kraft i Zolas roman Valfartsstedet}

\author{
KATRINE FRØKJÆR BAUNVIG
}

ENGLISH ABSTRACT: This article outlines the emergence of Lourdes as a shrine. This sketch records how procession practices seem important in the cultural grounding of the site. But the article's real center of attention is a study of how French author-jounalist and intellectual, Republican free-thinker, Émile Zola's novel Lourdes depicts processions. The novel is driven forth by a critique of contemporary religious life. Nevertheless, this critique is somewhat softened in the description of the ritual performances of the processions. Pertaining in particular to the interest in forcemetaphors, Zola in these passages shows a perhaps surprising resemblance to formative figures within the study of religion such as Émile Durkheim.

DANSK RESUME: Denne artikel skitserer fremvæksten af Lourdes som helligsted fra midten til slutningen af 1800-tallet. Denne skitse tegner blandt andet konturerne af processionspraksissers betydning for helligtstedets etablering. Men artiklens egentlige tyngdepunkt er undersøgelsen af processionsskildringerne $i$ den franske forfatterjournalist og intellektuelle, republikanske fritænker Émile Zolas roman Valfartsstedet fra 1894. Denne roman er en religions- og samtidskritik; men denne kritik nedtones påfaldende i beskrivelserne af processioners kraft og virkning. I disse passager viser Zola et måske overraskende slegtskab med den formative religionsvidenskabs interesse for 'religiøse kræfter' som den formuleres fx hos Émile Durkheim.

KEYWORDS: Lourdes; Émile Zola; procession; mariologi; apparition; pilgrimsfærd; valfart; skønlitteratur; Frankrig; Durkheim.

Processioner er gruppers lineært ordnede gang fra ét kendt punkt til et andet under brug af højtideligt-andægtige bevægelser og miner - en kollektiv bevægelse, som typisk vil være motiveret af et ønske om at bevidne, at frembære en hellig eller på anden måde vigtig genstand, at udføre et ritual, at opfylde et løfte, at opnå en for- 
tjeneste eller at besøge et helligsted. ${ }^{1}$ Således forstået er processioner en udbredt praksisform i aktuelle katolske gruppers ritualrepertoire, ${ }^{2}$ ligesom de har været det $\mathrm{i}$ den katolske kristendoms historie fra (særligt) højmiddelalderen og frem. Overensstemmelsen mellem Grimes' indkredsning og den katolske forståelse af veludførte processioner fremgår af den officielle beskrivelse af ritualerne i ritualhåndbogen Rituale Romanum. ${ }^{3}$ I gennemgangen af de overordnede processionskategorier - generales (for præsteskabet alene), ordinariae (årligt genkommende ritualer som procession Palmesøndag og Corpus Christi-processioner, hvor både præsteskab og lægfolk kan deltage) og extraordinariae (engangsprocessioner, som typisk foretages af præster og lægfolk i fællesskab, fx til indvielse af en kirkegård eller for at afværge en epidemi) - understreges det således som et fællestræk, at ritualdeltagerne skal være barhovedede og at disse skal gå roligt to og to i lige rækker.

Med flygtig reference til spændingsforholdet mellem anti-rituelle tankereflekser med rødder i protestantisk kristendom og rituel høj-artikulering eller 'fyldighed' i katolsk kristendom, ${ }^{4}$ nøjes jeg med at konstatere, at katolske eksempler er hyppige i akademiske indkredsninger af termen 'procession'. Corpus Christi-ritualer fremhæves således i Bernhard Langs processions-opslag i Religion Past and Present (2015); Via Dolorosa-processionerne i Jerusalem fremhæves i Ronald L. Grimes' tilsvarende opslag i Encyclopedia of Religion $(1987,7416)$. At eksemplerne høstes netop her er for sin del forståeligt, oplagt og følger et naturligt nærhedsprincip, eftersom ordet 'procession' tidligt bevægede sig fra sin romersk-latinske oprindelse og rodfæstede sig som en insider-term anvendt $\mathrm{i}$ kristne (katolske) miljøer og først relativt nyligt har løsnet sig tilstrækkeligt fra denne kontekst til at kunne føje grene med objekt- og metadiskurser - emic- og etic-kategorier - til sit semantiske domæne (jf. Jensen 2003, 109).

Denne artikel angår imidlertid ikke katolske processioner generelt; jeg vil i stedet fokusere på den praksis, som blev etableret ved den pyrenæiske by Lourdes fra begyndelsen af 1860 'erne efter den unge pige Bernadette Soubrious' erklærede syner af jomfru Maria. Det drejer sig nærmere bestemt om den måde, hvorpå forfatterjournalisten og den intellektuelle, republikanske fritænker Émile Zola (1840-1902) fremstillede disse processioners rolle i det bureaukratisk og kommercielt veludbyggede kirkelige foretagende, som Lourdes havde udviklet sig til i begyndelsen af 1890'erne. Zola udformede sit billede af byen i romanen Lourdes fra 1894, som blev en salgssucces og udgangspunktet for en voldsom offentlig debat om helligstedet specifikt og forholdet mellem religion og videnskab generelt. Debatten slog ud i en lang række indlæg i den offentlige presse formuleret som kritik af Zola (Harris 1999,

1 Dette er i store træk Hans J. Lundager Jensens fordanskning af Ronald L. Grimes definition (Grimes 1987, 7416) fra indledningsartikelen til dette nummer af RvT.

2 Herom vidner såvel forskningsartikler (fx Seales 2008) som aktivitetskalendre og katolske opslagsværker. Se fx på http://www.thequeenofangels.com.

3 Dette gælder både for 1853-udgaven (på latin), hvori processionsforordningerne findes s. 398-473, og 1962-udgaven (på engelsk), som er digitaliseret og tilgængelig på http://www.sanctamissa.org. 1853-udgaven kan tilgås på http://www.saintsbooks.net.

4 Denne spænding er almenkendt og velbelyst i litteraturen, der rummer både forskningskritik som hos fx Mary Douglas (1966, 62ff) og praksiskritik som hos fx Søren Ulrik Thomsen (2005). 
339-349). Men også reaktioner som spydige satiretegninger ${ }^{5}$ og skønlitterære ${ }^{6}$ modsvar florerede. Centralt i Zolas fortælling står processionspraksissen, og denne centrale placering afspejler en række interessante aspekter ved fransk intellektuel kultur med konsekvenser ikke mindst for tidlig religionsvidenskab i den første periode af Den Tredje Republik (Frankrig fra 1870 til 1940). Men før jeg når til udfoldelsen af de forhold, der væver sig sammen til denne påstand, er det nødvendigt at give en indføring i, hvorledes Lourdes voksede frem som helligsted. Men også før jeg kan vende mig mod etableringen af dette historiske bagtæppe, skylder jeg to indledende afklaringer. Den ene gælder anvendelsen af skønlitteratur som kildemateriale; den anden angår processioners fremkomst i den kulturelle evolution.

Det sidste først: Hans J. Lundager Jensen peger på to vigtige og internt forbundne omstændigheder i indledningen til dette nummer af Religionsvidenskabeligt Tidsskrift. Den ene er, at det er plausibelt, at processioner i et kultur-evolutionært perspektiv er fænomener, der finder gunstige forhold i byer og med en vis grad af sandsynlighed kan siges at repræsentere en væsentlig, rituel udtryksform i den periode, som Robert N. Bellah ville kalde arkaisk (Bellah 1964, 364-365; 2011, 210-264). Den anden omstændighed er, at processioner (måske derfor) i dag gerne opfattes som anakronistiske indslag fra hensvundne tider - 'survivals': Jeg anfører disse forslag som centrale referencepunkter for min behandling af Lourdes som en 1800-talsprocessions-case. Denne case accentuerer nemlig en spænding i forholdet mellem netop land og by og indkapsler denne spænding i noget, man måske kunne tænke på som nostalgisk, romantisk eller slet og ret som et 'tidsforskydnings-tema'.

Hvad angår mit afsæt i Zolas roman: Allerede på dette punkt, før artiklen er løbet egentligt i gang, skylder jeg oplysninger om den status, jeg tilkender Zolas tekst som adgang til viden om Lourdes. Hvilken forbindelse er der mellem de faktiske forhold i fromhedslivet og religionsindustrien i Lourdes på den ene side og Zolas polemiske bog på den anden? Naturligvis ikke nogen klar og direkte relation. I en vis forstand må historiske undersøgelser, der indkalder skiftende samtiders skønlitteratur som vidner, stille sig tilfreds med den genfærdsagtige kvalitet, teksterne nødvendigvis er kendetegnet ved: På afstand synes man ikke længere at have adgang til de spørgsmål eller den umiddelbare kontekst, som motiverede den litterære tilblivelse. I en vis forstand står man alene tilbage med en samling 'svar'. Dette er i hvert fald den italienske litteraturforsker Franco Morettis tilbageholdende vurdering af den udsagnskraft, han vil tildele sit roman-korpus. Ikke desto mindre er dette korpus genstanden for hans udforskning af The Bourgeois. Between History and Literature (2014, 12-14). Men denne metodiske begrænsning er gammelkendt i humanvidenskaberne, der i det 20. århundrede fostrede mentalitetshistorien som disciplin og Annales-skolen som forskningsfællesskab. Den pointe, jeg skriver mig hen imod, er, at til trods for, at Zolas bog er blevet til som resultatet af en grundig

5 Se fx på http://www.alamy.com.

$6 \quad$ Et eksempel på sidstnævnte kunne være den prominente, vækkelseskatolske Joris-Karl Huysmans' (1848-1907) Les foules de Lourdes fra 1906. Den forholder sig mange steder direkte, aktivt og overordentligt kritisk til Zolas tekst. Jeg henviser her til den engelske posthume oversættelse fra 1925, hvor Zolas fremstilling afvises gang på gang. Et tilfældigt nedslag i denne: s. 252. 
research med flere besøg i Lourdes, er den først og fremmest en levnskilde til den heftige debat om religion, som foregik i årtierne på begge sider af år 1900 i Frankrig mellem (primært sekulære) republikanere og (primært katolske) monarkister. Zolas beretning anfægtede og provokerede de sidstnævnte på en række punkter, hvoraf det, man opfattede som forvanskninger af visse almenkendte mirakuløse helbredelsesberetninger, er det mest afgørende. Men visse elementer i fortællingen vakte ikke anstød og blev ikke påtalt. I den forstand kan den heftige debat måske siges at blotlægge de tråde i Zolas beskrivelse, som var relativt konsensusprægede og som muligvis giver adgang til halv-sikker viden om (i det mindste opfattelsen af), hvad der foregik i Lourdes. Blandt disse tråde er den mest iøjnefaldende Zolas beskrivelser af processionerne. Med disse indledende tilløb og afgrænsninger til sagen.

\section{Lourdes. Fremvæksten af et helligsted}

I løbet af februar 1858 hævdede den fattige og astmatisk-tuberkuløse Bernadette Soubrious (1844-1879), at jomfru Maria viste sig for hende. Bernadette Soubrious så hende, da hun var i færd med at samle brænde på fælleden udenfor den undseelige, pyrenæiske by Lourdes. Jomfru Maria viste sig nærmere bestemt for den fjortenårige pige 16 gange ved Massabielle-grotten nær ved den lokale kilde i februar og marts, hvor hun lod Bernadette forstå, at vandet besad hellige kræfter og at hun ønskede, at man opførte et kapel ved kildens udspring og etablerede en processionspraksis. Hurtigt tiltrak rygtet om Soubrious' erfaringer sig opmærksomhed og store folkemængder forsamlede sig jævnligt omkring grotten til de lokale myndigheders ærgrelse (Weber 1976, 353).

Dette er de allertykkeste hovedlinjer i den fortælling, som hurtigt blev udbredt. Først mundtligt i nærområdet, siden skriftligt til Frankrig og hele verden. Et afgørende medie i den skriftlige udbredelse var skønlitterære bearbejdninger, hvoraf den katolske journalist Henri Lasserres (1828-1900) sentimentalt-romantiserende Notre-Dame de Lourdes fra 1869 var særligt afgørende og har dannet grundlag for mange gendigtninger af episoden (Harris 1999, 177-209). Men besværer man sig ned under standardberetningen til samtidskilderne, gemmer der sig religionsfagligt relevante oplysninger om, hvordan helligsteder, apparitioner og processions- og pilgrimspraksis bundfældes og accepteres af religiøse fællesskaber. Forarbejdet til sådanne overvejelser har historikeren Ruth Harris foretaget i Lourdes. Body and Spirit in the Secular Age fra 1999, som jeg læner mig op ad i det følgende.

Løfter man blikket fra Lourdes til den katolske verden som sådan, bliver det hurtigt tydeligt, at Bernadettes Soubrious erklærede erfaringer må opfattes som en del af en generel apparitionstrend, der udfoldede sig i store dele af Europa i det lange 19. århundrede frem til Første Verdenskrig (Blackbourn 1994, 3-41). De mest velkendte og kirkeligt accepterede eksempler er visionerne knyttet til Rue du Bac i Paris og nonnen Catharine Labouré i 1830, som førte til lignende beretninger hos nonner i Venedig i begyndelsen af 1840'erne. Hertil kommer den italiensk-jødiske bankmand Alphonse Ratisbonne fra Rom, der efter en vision i 1842 konverterede til 
katolicismen. Men begivenheder i 1850'ernes Lichén i Polen, bøhmiske Phillipsdorf i 1866, irske Knock i 1879, italienske Castelpetroso i 1888 og ikke mindst portugisiske Fátima i 1917 bør også medregnes (Maunder 2016, 19-21). Disse eksempler er endvidere blot en lille del af det, som religionshistorikeren Chris Maunder betragter som den officielle og anerkendte top af et folkereligiøst isbjerg (ibid.). En tillægsbetragtning i forbifarten bør være, at disse tendenser repræsenterer en utvetydig 'feminisering' af det folkereligiøse udtryk (jf. Woodhead 2004, 144-156; van Osselaer 2014, 7): $74 \%$ af de anerkendte 1800-tals-apparitister var kvinder (Maunder 2016, 53).

I det hele taget stod dyrkelsen af jomfru Maria stærkt i såvel den folkereligiøse praksis som i den elitært-teologiske refleksion i 1800-tallet. Måske særlig stærkt i det post-revolutionære Frankrig: ${ }^{7}$ Man kan se omridset af dette i den omstændighed, at der hvert år fra 1802 frem til 1898 blev oprettet en ny religiøs orden eller lægmandsdrevet kirkelig organisation i jomfru Marias navn (Maunder 2016, 18). At de fleste af disse blev oprettet i Frankrig, virker endvidere mindre overraskende, når man konsulterer digitale tekstkorpora som Google Books. ${ }^{8}$ En søgning i det franske delkorpus viser således, at udtryk som 'Vierge Marie', 'Notre Dame' og 'Sainte Mère' steg markant i de første tre fjerdedele af det 19. århundrede; årene midt i 1850'erne står imidlertid som et særligt højdepunkt. ${ }^{9}$ Omtaler af pave Pius IX's encyklika vedrørende jomfru Marias ubesmittede undfangelse fra 1854 kunne være den oplagte forklaring herpå. ${ }^{10}$ Denne artikels emne taget i betragtning er det desuden interessant, at pavens reaktion på forfatteren Henri Lasserres ovennævnte succesroman giver udtryk for en samklang mellem folkelige og den kirkelige elites interesser, hvad angår Lourdes. I et brev fra 1869 takker pave Pius IX således Lasserre for bogen og for at 'grundfæste sandheden om den nylige apparition', som han anser for at være et slagkraftigt religiøst redskab:

Vi er sikre i den overbevisning, at hun [Vor Frue af Lourdes] - som tiltrækker sig massevis af pilgrimme fra alle egne ved de mirakler, som hun bevirker ved sin kraft og godhed - at hun på samme vis ønsker at benytte sig af din bog til at udbrede sit budskab og til at opflamme menneskehedens fromhed og tiltro med henblik på, at alle må få del i den overflod, som er hendes nådegaver. ${ }^{11}$

7 For en introduktion til emnet katolicismens stilling i Frankrig under og efter revolutionen, se Nigel Astons Religion and Revolution in France, 1789-1804 (2000). Men også Eugen Webers klassiske Peasants into Frenchmen, kapitel 19 og 20 (1976, 339-374), er værdifuld i denne sammenhæng.

8 Dette korpus består af omtrent 150 millioner titler på verdensplan. For en tilgængelig indføring i dette korpus' relevans i humanvidenskabelig forskning se Mads Rosendahl Thomsen (2013).

9 Denne søgning er foretaget via https://books.google.com/ngrams/.

10 Dette dogme angår den opfattelse, som har floreret i det kristne forestillingsunivers siden senantikken, at jomfru Maria til trods for sin biologiske undfangelse var ubesmittet af arvesynden. Men forestillingen fik altså først en pavelig godkendelse i 1854 (jf. Warner 2003, 241-260). I engelsk oversættelse lyder et centralt uddrag af 1854-encyklicaen således: “the most Blessed Virgin Mary, in the first instance of her conception, by a singular grace and privilege granted by Almighty God, in view of the merits of Jesus Christ, the Saviour of the human race, was preserved free from all stain of original sin" Teksten tilgås på http://www.ewtn.com.

11 Dette er mit oversættelsesudkast til et udsnit af brevet, som er skrevet på latin. Det er optrykt på latin og engelsk i den engelske oversættelse af romanen fra 1906 på side 4-6 og kan tilgås på https://archive.org. 
Citatet antyder, at der allerede ti år efter synerne var etableret en folkelig pilgrimspraksis og en kirkelig konsensus om, at Bernadette Soubrious' syner var sande. Langt fra alle apparitioner var udgangspunkt for konstruktionen af et helligsted og en religiøs dyrkelse, ligesom hovedparten ikke blev officielt godkendt af de kirkelige myndigheder (Maunder 2016, 1). På den baggrund er det oplagt at spørge, hvorfor netop hændelserne i Lourdes førte til fremvæksten af et af de mest succesfulde kristne helligsteder i moderne tid? Dette spørgsmål kan udspaltes i to lige afgørende dele: Hvorfor troede almindelige mennesker på hende? Og hvorfor sanktionerede kirken hendes syner? Begge emner er (naturligvis) for omfattende til at udtømme i en (enkelt) artikel, hvorfor man må nøjes med to oversigtsdannende skitser til svar.

Et tilløb til en besvarelse af det første spørgsmål tager sit afsæt i det, man måske kunne kalde de folkelige forventninger blandt de første som troede på Bernadette Soubrious: befolkningen i Lourdes, les lourdais. Flere forhold synes nemlig at pege på, at det for beboerne i denne egn ikke ville være modintuitivt, at en ung pige skulle kunne komme i kontakt med jomfru Maria. Tværtimod taler meget for, at det ligefrem forekom plausibelt, at noget sådant kunne foregå. En levende tradition med flere hundrede år på bagen kunne i hvert fald indikere dette. Siden den vækkelsesperiode, man ofte omtaler som den katolske modreformation, og blandt hvis hovedfigurer man kan fremhæve Ignatius af Loyola (1491-1556), Teresa af Ávila (15151582), Johannes af korset (1542-1591) og Frans af Sales (1567-1622), fremkom mange eksempler på Maria-apparitioner. I denne sammenhæng er det mest væsentlige tilfælde den pyrenæiske kulturlegende, der kredser om den tolvårige pige Anglèze de Sagazan, som i 1515 hævdede at se jomfru Maria i den lille by Garaison, som ligger omtrent $70 \mathrm{~km}$ fra Lourdes. Sagazans syner blev omsat til et valfartssted, og myterne om hende fungerede som en dyb historisk reference for Soubrious-tilhængere i 1800-tallet. Bernadette lignede ganske enkelt, sagde man, Anglèze (Harris 1999, 40). Hertil kommer spørgsmål om den udannede Bernadette Soubrious' personlighed, 'karisma' og 'autenticitet': Hun gjorde stærkt indtryk på sine tilskuere og virkede troskyldigt pålidelig; hun levede med andre ord op til befolkningens æstetiske, mentale og moralske forventninger til en ung apparitist (Harris 1999, 157-165). På historisk og akademisk afstand forvandler trangen til håndfast verifikation af denne slags betragtninger sig dog oftest til metodiske genstridigheder, og man gør bedst i at give afkald på at konkludere noget endegyldigt herom.

Derfor er det mere tillokkende at vende blikket mod visionernes fysiske omgivelser. For der synes at være grund til at antage, at disse var velvalgte, hvis målet var at overbevise lokalbefolkningen om synernes gyldighed. Området omkring grotten var nemlig udgangspunkt for en forbindelse med overnaturlige væsener. Under alle omstændigheder levede feer, hekse, varulve og dæmoner i grænselandet mellem byen og det egentlige bjergvildnis ifølge den mundtlige overlevering. Derfor var det eksempelvis en udbredt praksis at slå korsets tegn, når man nærmede sig området, hvor grotten ligger (Harris 1999, 52-54). At en ung pige netop her skulle få kontakt med og del i en overnaturlig kraft, var man med andre ord forberedt på i den lokale befolkning. Denne opfattelse blev desuden bestyrket og regelmæssigt vedligeholdt af de helbredelsesberetninger, som blomstrede op få år efter 1858. 
Der var således træk ved Bernadette Soubrious' person, den lokalhistoriske kulturarv og tolkningen af nærlandskabet, som lod apparitionerne fremstå troværdige for Lourdes-befolkningen. Men forestillingerne synes at have vundet i styrke på grund af de fakkelprocessioner, som lokalbefolkningen gennemførte allerede fra foråret 1858 (Harris 1999, 83); disse rituelle handlinger gav Bernadette-følgerne en kollektiv identitet og forankrede de nye forestillinger $\mathrm{i}$ en fysisk praksis, foreslår Ruth Harris $(1999,91)$.

Så vidt les lourdais. Men hvorfor troede den kirkelige elite på hende? Det gjorde den heller ikke til at begynde med. De kirkelige myndigheder med forankring i den lokale abbé Dominique Peyramale (1811-1877) ${ }^{12}$ forholdt sig tværtimod forventeligt skeptisk til sagen. Fra centralt hold nedsattes dog allerede i 1858 en kirkelig undersøgelseskommission, som skulle interviewe vidner og i første omgang vurdere Bernadettes personlige troværdighed og herefter indholdet af hendes erfaringer. Hovedbesværligheden for kirken var Bernadettes beskrivelse af genstanden for sine syner: Den fjortenårige pige forklarede sine omgivelser på det lokale patois, ${ }^{13}$ at hun havde set 'uo pétito damizélo' (en lille ungpige) klædt i hvidt. Andre gange talte hun om skikkelsen som en 'aquero' (et lille vandvæsen). Under en af de sidste apparitioner hørte Bernadette væsenet sige 'soy era Immaculada Councepciou' (jeg er den Ubesmittede Undfangelse; Harris 1999, 55-82). Men det gik imod det centrale maternalistiske punkt i det almindelige mariologiske forestillingskompleks, at Bernadette fastholdt, at hun så en lille pige og ikke en kønsmoden kvinde. For det andet var det en smule dogmatisk akavet, at Bernadette insisterede på, at skabningen havde sagt, at hun var 'den ubesmittede undfangelse' (ibid., 80-81). Teologisk spiselige udsagn ville have været noget i retningen af 'den ubesmittede moder' eller 'den ubesmittede jomfru'. ${ }^{14}$ I såvel den folkelige som den kirkelige behandling af sagen forvandlede denne omstændighed sig imidlertid efterhånden og på paradoksal vis til et tegn på Bernadettes enfoldige oprigtighed. Med andre ord vendte man den teologiske ukorrekthed på hovedet og betragtede den som en omstændighed, der slet og ret styrkede hendes troværdighed. I 1862 kundgjorde biskoppen af Tarbes således, at den katolske kirke betragtede apparitionerne som sande (Weber 1976, 353).

Men de processioner, som hurtigt op gennem 1860'erne samlede sig til en egentlig genkommende praksis med Massabielle-grotten som endemål, skulle vise sig at være afgørende for den mentale rodfæstning af den kirkelige godkendelse. Ligesom processionerne skabte sammenhængskraft i lægmandsbevægelsen i Lourdes, gjorde de stærkt og positivt indtryk på de klerikale besøgende, der kom stadig flere og fle-

12 Det franske ord 'abbé', som oprindeligt kommer af det græske 'abbas' og dermed er forbundet med det danske 'abbed' og det engelske 'abbot', anvendes om laverestående gejstlige som sognepræster, hvilket Peyramale netop var.

13 For en beskrivelse af det særdeles brogede sproglandskab, som Frankrig bestod af helt frem til slutningen af 1800-tallet og som besværliggjorde skiftende statsmagters centraliseringsbestræbelser, se Weber 1976, 67-94.

14 Denne formulering var Bernadette Soubrious imidlertid ikke ene om. Faktisk er den efterhånden gledet ind i sproget som et folkeligt standardudtryk, hvilket diverse opslagsværker ofte påpeger. 
re af. En repræsentant for disse besøgende kunne være abbé Chocarne af Beaune. Ruth Harris gengiver hans beskrivelse af sin rejse til Lourdes i oktober 1871. Han lagde stor vægt på oplevelsen af en procession fra den nærvedliggende by Bigorre til Lourdes. Der var nemlig tale om 'en af den slags landlige processioner [...], som fremmede holder af på grund af deres enkelhed og glød [éclat], den fromme alvor og ynde, som er indbegrebet af deres charme' (Harris 1999, 253) $\cdot{ }^{15}$ Chocarne mente med andre ord at have været vidne til et autentisk landligt fromhedsliv eksemplificeret ved blomsterpyntede ungpigers 'gravité pieuse'; et fromhedsliv, der var uspoleret og upåvirket af civilisatoriske fremskridt, og som havde bevaret et oprindeligt middelalderligt religiøst liv (Harris 199, 255-258; jf. Kaufmann 2005, 64). Fascinationen af og sammenkoblingen mellem landlig idyl, 'middelalderisme' og autentisk folkereligiøsitet er et fænomen, som præger adskillige vidensfelter i 1800-tallet. Chocarnes begejstring er på ingen måde enestående: De nye videnskabelige discipliner, etnografien og folkloristikken, er eksempler på, at denne sammenkædning omsatte sig til konkrete institutionelle enheder rundt om på de europæiske universiteter (Burke 2008; Ziolkowski 1990). I Frankrig fandt denne mentalitetshistoriske trend imidlertid sine tydeligste formuleringer hos den franske romantiks frontfigur, François-René de Chateaubriand (1768-1848). Særligt værket Génie du Christianisme (1802 [1828]) er relevant at fremdrage. Chateaubriand indlejrer en hyldest til den rustikke og middelalder-gotiske folkereligiøsitet anno $1800 \mathrm{i}$ sin post-revolutionære beskrivelse af den 'kristne ånd og skønhed'. Bogen er momentvist udarbejdet som proto-antropologiske rejsebeskrivelser, hvori Chateaubriand fx omtaler kristne som værende i besiddelse af dybe æstetiske erkendelser, ligesom han fremhæver landsbykirkelige processioner som indbegrebet af en regenerativ religiøsitet $(1871,473 \mathrm{ff}$.). Præsten Chocarnes romantiske rapportering af sine oplevelser i efteråret 1871 gjorde således brug af en velkendt intellektuel trope i sin understregning af processionens betydning i Lourdes.

I 1866 blev Lourdes endvidere integreret i det omsiggribende franske jernbanenet, hvorved den nationale pilgrimsfærd til grotten og kilden blev mulig (Weber 1976 , 354). Interessen for valfarten tog hastigt til op gennem den sidste tredjedel af 1800-tallet. Et voksende antal helbredelsesberetninger ansporede denne udvikling, ligesom den franske monastiske orden Assumptionisternes systematisering af pilgrimsfærden til og plejebehandlingen af syge, les malades, i Lourdes fra 1873 og fremefter understøttede den. Syge drog til Lourdes og rapporterede om helbredelser for en lang række fysiske lidelser, hvorfor katolske myndigheder i 1883 oprettede et såkaldt Medicinsk Bureau til validerende undersøgelse af disse beretninger (Harris 1999, 261ff). For denne artikels overordnede fokus er det afgørende at understrege, at den rituelle processionspraksis stod centralt i disse helbredelsesberetninger. Foruden hændelser forbundet med badning i kildevandet fandt miraklerne med andre ord ofte sted under påvirkning af den kraft, som udgik fra ritualerne. Dette var i hvert fald en udbredt opfattelse blandt de besøgende (ibid.).

15 Dette er min oversættelse af et uddrag af Chocarnes artikel "Le Pèlerinage national", som udkom i det religiøse tidsskrift Le Pèlerin nr. 1 d. 12. juli 1873, p. 4, og er gengivet i Harris 1999, 253-254. 


\section{Zolas roman Valfartsstedet (1894)}

Hen imod slutningen af 1800-tallet havde Lourdes forvandlet sig fra en fattig afsidesliggende provinslandsby til et attraktivt, pilgrimsbaseret kommercielt centrum. Det er derfor ikke overraskende, at den tyske historiker Jürgen Osterhammel placerer Lourdes i den overordnede kategori af 'en-funktionelle' byer, hvis omfang på verdensplan var en karakteristisk ny tendens for det 19. århundrede. Sølvminebyen Potosí i Bolivia, men også jernbanebyer som Nairobi i Kenya eller friluftstilbud som Spa i Belgien kunne være gode eksempler på de forskellige former for specialiserede byer, der voksede frem i denne periode (Osterhammel 2009, 264-275).

Det var således en by i vækst med handlende og brede, brostensbelagte boulevarder finansieret af de mange valfartende, som Émile Zola besøgte, da han rejste til Lourdes i 1891 og 1892 (jf. Kaufmann 2005, 63). Netop det systematisk-omfattende og kapitalistisk-kommercialiserede moment ved den religiøse industri træder frem som en kritik i den roman, der blev resultatet af Zolas besøg. Bogen udkom på fransk som Lourdes i 1894 og blev oversat til dansk samme år under titlen Valfartsstedet. Som Henri Lasserres udgivelse 25 år tidligere fik Zolas en stor betydning for behandlingen af helligstedet $\mathrm{i}$ den offentlige debat i Frankrig. Hertil kommer, at bogen på glimrende vis illustrerer de pointer, som Zola kondenserede i sin 'naturalistiske' idé om en roman expérimental - en genre, som i eksplicit konkurrence med nye fagdiscipliner som $\mathrm{fx}$ sociologien skulle spille en samfundsmæssig betydningsfuld rolle ved at underkaste problemer en litterær vivisektion og dermed føre til refleksion og debat (Lepines 2006, 96-97). De problemer, som han fandt mest presserende, var forholdet mellem arv og miljø samt religion og videnskab, hvilket mundede ud i en overordnet kritik af den borgerlige moral (Schom 2015). Alle disse temaer er tilstede i Valfartsstedet.

Historien udspiller sig under en fem-dages rejse til og fra Lourdes. Der er tale om en paradoksal kærlighedshistorie mellem den unge, katolske præst Pierre Froment og hans smukke, lamme barndomsveninde Marie de Guersaint. Pierre befinder sig i en religiøs krise og føler sig hyklerisk i sin stilling som præst. Zola sniger på den baggrund ubesværet et ekko af 1800-tallets dominerende religions- og socialkritik ind i Pierres tankerækker: "Overtro svækker og fordummer, skaber en ussel, frygtsom Slægt - der lettelig bliver Bytte for de Onde og de Stærke" (Zola 1894, 768). ${ }^{16}$ Et genkommende problem for Pierre er, hvordan han med sin integritet i behold kan prædike fasthed i tro og levevis, når han selv tumler med tvivl og seksuelle lyster. Den ambivalente længsel efter en nu desværre vissen, men engang saftfyldt og spændstig barnetro er et beslægtet omkvæd; Pierre venter således på det 'Lynslag', som ville kunne "vække hans Barnetro fra de Døde og gøre ham til et enfoldigt, tillidsfuldt Væsen, der glad gav sig Gud i Vold" (ibid., 442). Med håb om, at Lourdes vil danne de rette omgivelser for en sådan revitalisering, lader han sig overtale af Marie til at ledsage hende og hendes far på en af pilgrimsrejserne arrangeret af As-

16 Her og i det følgende citeres fra den danske 1894-oversættelse, men jeg har konsulteret den franske udgave stillet til rådighed $\mathrm{i}$ pdf-format af La Bibliothèque électronique Québec på https://beq.ebooksgratuits.com. 
sumptionisterne. Turen går fra Paris med tog i en kupé overfyldt med tuberkuløse, kræftsyge og invalide fattigfolk. Men persongalleriet rummer også en lang række højtstående borgere, der er taget til Lourdes for at flirte og for at udføre opgaver forbundet med plejen af de syge.

Marie vil besøge 'Mirakelgrotten' og bade i kilden i håb om, at den hellige jomfru vil lade hende genvinde sin førlighed. Den mistede hun i en rideulykke i trettenårsalderen, ikke lang tid efter sin mors død. Adskillige læger har tilset hende og vurderet, at der er tale om en psykosomatisk lidelse, som i datidens vokabular omtales som 'hysteri' (Zola 1894, 40). ${ }^{17}$ Ikke desto mindre henlever hun i en art kiste på hjul, som hun trilles rundt $i$, da hun når frem til Lourdes. Her samler Maries håb om helbredelse sig gradvist til vished. Et afgørende skred sker ud på aftenen på rejsens anden dag under en procession udformet som fakkeloptog (ibid. 391-418). Om natten herefter ser Marie jomfru Maria, der uden ord lader hende forstå, at hun, Marie, vil blive helbredt den næste dag kl. 16 under nadverprocessionen. Denne procession og Maries helbredelse er bogens narrative tyngdepunkt. Da Marie er reddet, får hun sin helbredelse godkendt af det Medicinske Bureau (ibid. 555); men Pierre får ikke retableret sin barnetro af miraklet. Under togturen på vej hjem til Paris slutter hovedpersonen imidlertid fred med sin fornuft og ønsker sig ikke længere tilbage til en fast tro på "det guddommelige Blændværk, der er Oprindelsen til enhver Religion" (ibid., 771). Til trods for denne erkendelse byder Pierres ære ham at holde sit præsteløfte, så kærlighedshistorien ender ulykkeligt: Marie vender giftemoden og vital hjem til Paris; men Pierre ofrer sin seksualdrift og fastholder sin stilling og cølibat.

Fortællingen er skrevet med afsæt i en klart markeret social indignation ('fattig', 'pauvre', er således et nøgleord), ligesom den forholder sig staveplade-tydeligt til religiøsitet som et enfoldigt og forkrøblende værensmodus. Det er svært ikke at opfatte denne tekst som en kritik af på den ene side kirken, der lukrerer på en afmattet og desperat underklasse, og på den anden side en velbjerget middelklasse, der tager på velgørenhedsferie i det sydfranske for at pleje syge og egen samvittighed. Men i beskrivelsen af netop processionerne svækkes denne kritiske tone af en forundring over det rituelt virkningsfulde ved disse begivenheder.

\section{Diffuse og klare processioner}

Som det fremgår af ovenstående, er der indvævet to processioner i bogen. Begge spiller afgørende roller for historien: Fakkelprocessionen om aftenen kl. 21 hensætter Marie i en liminal, trancelignende tilstand, der først afsluttes under nadverprocessionen den efterfølgende dag kl. 16, da hun bliver helbredt. Den første procession foretages af "Mer end tredive Tusinde Pilgrimme" (Zola 1894, 391), hvoraf langt hovedparten er "Kvinder [...] med simple og grimme Træk [... og med] et himmelsk forklaret Udtryk" i ansigtet (ibid., 408); alle bærer de "en Vokskærte i Haanden, indsvøbt i et Slags Kræmmerhus af hvidt Papir", som har påtrykt et "Billede af

17 For en oversigt over hysteriets kulturhistorie i det 19. århundrede, se Logan 1997, kapitel 1. 
den hellige Jomfru fra Lourdes" (ibid., 394). Ruten går fra den nye kirkebygning ${ }^{18}$ til grotten rundt om et haveanlæg, hvor en statue af "den kronede Jomfru" befinder sig (ibid., 406), og tilbage igen. I haven sidder Pierre og Marie i tosomhed og ser optoget. De hører på afstand den hypnotiske gentagelse af "Visen om Bernadette med de seks Dusin Vers" og den endeløse “vuggende Rytme: Ave, ave, ave, Maria!" (ibid., 397).

Den anden procession foretages ved højlys dag af "Udsendinge fra Pilgrimstogene", som bærer bannere med "forskellige Byers Navne, saasom: Versailles, Reims, Orleans, Poitiers, Toulouse." Disse udsendinge er hovedsageligt mænd, hvilket et af bannernes tekst antyder: 'De katolske Arbejderforeninger' (ibid., 546). Efter pilgrimmene kommer "to, tre Hundrede Præster, i den almindelige sorte Dragt, hundrede i hvid Messeskjorte og halvt saa mange iførte pragtfuldt broderede, brogede Messehagler," der funkler "i alle Regnbuens Farver" (ibid., 547). Processionen, som går i lige linje fra den nye kirkebygning til grotten og tilbage igen, er omgivet af en stor og voldsom folkemængde, der er blevet stærkt ophidset af en lang række bønner ført an af skiftende præster (ibid., 531-538): “Jesus, Davids søn, helbred vore Syge!" (ibid., 544) lyder det igen og igen (ibid., 540. 544. 545. 547. 548. 549), ligesom den ledende pater Massias proklamerer: "Herren har sét ned til sine Børn! Herren har besøgt sin Menighed!" (ibid., 552) efter Maries helbredelse.

Der er således nogle påfaldende strukturelle forskelle i Zolas beskrivelse af disse to processioner. Den ene er knyttet til jomfru Maria, en amorf-anonym lægkvindemasse og meditativ sang. Den anden er knyttet til Jesus og det maskuline præsteskab, en eksalteret folkemængde og et punktuelt mirakel. Det ene optog observeres som en fjern flok, der slår en fredelig lyscirkel i horisonten. Det andet beskyttes af en afspærring (ibid., 545-546) og trues med kollaps under presset fra den store “Vrimmels ubevidste Magt" (ibid., 532). I den ene procession er aftenluften "mild og behagelig som et lunkent bad" (ibid., 392), og iagttages af Pierre og Marie fra en have, hvor der dufter 'gaadefuldt' af roser (ibid., 399. 403. 405). Her bør det indskydes, at denne beskrivelse trækker på en række forestillinger - som var særligt udbredt i middelalderlige kristendomsformer - om jomfru Maria som en have, ${ }^{19}$ om statuers magiske kræfter (Bynum 2011, 129ff) og om hellighed som en kvalitet, der måles på sød duft. ${ }^{20}$ Dette kunne for sin del antyde, at Zola har ønsket at fremskrive en sammenhæng mellem dette optog som udtryk for en lægmandsfromhed uspoleret af de kirkelige myndigheder i kontakt med sine kulturelle og religiøse middelalderrødder, ligesom han synes at forsøge at placere forestillingen om det, man måske kunne kalde en snigende hierofani: at jomfru Maria gradvist som en sivende duft-

18 I den danske oversættelse hedder det 'Basilikaen'. Der er tale om Basilique de l'immaculée Conception, som blev opført nær ved grotten mellem 1866 og 1872.

19 Jeg sigter her til forestillingen om jomfru Maria som en 'Hortus Conclusus' (en aflukket have). Forestillingen voksede frem i høj- og senmiddelalderlig poesi og har dannet grundlag for mange billedkunstneriske fremstillinger af jomfru Maria (Granziera 2002, 263).

20 Denne logik er vidt udbredt i kristendommens historie, hvorfra middelalderlige beskrivelser af helgeners kropslugte tilbyder sig som oplagte eksempler. For en aktuel og særdeles velskrevet analyse af et sådant fænomen se Hans J. Lundager Jensens “Maria Magdalene i Provence. Tribal og post-aksial askese" (2016). 
sky fylder haven, hendes rette habitat, med sin tilstedeværelse. En sådan udlægning kunne siges at bekræftes af den besked, som Marie modtager fra den hellige jomfru i løbet af natten. At haven er af afgørende betydning, understreges under alle omstændigheder af Maries far, Hr. Guersaint. Han har set aftenoptoget fra en udkigspost og sammenligner fakkel-cirklen omkring den med en monstrans, hvor "Hostien var den runde Plæne"(ibid., 409). Monstranser er en katolsk liturgisk, pokallignende genstand, der i et hul i midten indeholder det indviede nadverbrød, hostie. Ifølge katolsk teologi er dette brød efter indvielse genstand for 'Kristi realpræsens'. Hr. Guersaints sammenligning gøder med andre ord jorden for forestillinger om et guddommeligt nærvær i parkanlægget; alle (de andre) billeder og beskrivelser peger på tilstedeværelsen af jomfru Maria og ikke Jesus.

Hvis luften er mild og rosenduftende under aftenprocessionen, er den kvælende 'beklumret' (ibid., 534), da Pierre og Marie befinder sig inde i folkemængden til eftermiddagsoptoget. Men efter Maries helbredelse, hvor de går som en del af processionsfølget og nyder udsigten over byen og bjerglandskabet, er luften klar og blå (ibid., 567). Til trods for, at 'beklumret' beskriver en olfaktorisk-sundhedssmæssig kvalitet af luften som ram og indelukket og udtryk som "Luftens stille blaa Sø" (ibid., 568) anvendes om visuelt-æstetiske evner til at formidle udsigten, synes Maries mirakel ikke desto mindre at have en rensende effekt.

Begge processionsbegivenheder beskrives desuden i pyrodynamiske termer. Ilden besidder egenskaber, der lægger sig strukturelt i forlængelse af det ovenstående. Aftenprocessionen er således kendetegnet ved de mange kærter, som danner en udflydende masse, en "levende Vandflade" (ibid., 394), hvor skælvende lys undertiden er 'Bølger', et 'Hav'21 (ibid.), en 'uudtømmelig Kilde' (ibid., 408) andre gange en 'Ildtaage' (ibid., 405), en 'Flod' (ibid., 406) eller blot noget, der "smelter sammen til en Sø" (ibid., 417). Der er med andre ord tale om en amorf, vandig ild, der oplyser mørket fra neden som en kunstig 'Morgenrøde' (ibid., 405) eller en kunstig "Flamme i Zigzag ligesom de Lynstraaler, man paa gamle Billeder ser slaa ned fra en mørk Himmel” (ibid., 396). Flere gange er der endvidere "Uorden i Marshen" (ibid., 407), og processionsmassen kan være vaklende, usikker og i fare for at gå i opløsning (ibid., 404). Anderledes forholder det sig med nadverprocessionen. Denne foregår ved højlys dag og er klart defineret af et bestemt antal pilgrimme og et bestemt antal præster i passende og flotte klæder (ibid. 546). En af præsterne bærer desuden rundt på en monstrans. I kraft af den indviede hosties kvalitet som vehikel for guddommelig tilstedeværelse, anses monstranser for at besidde en særlig kraft -

21 Med denne beskrivelse stiller Zola sig i rækken af forfattere, som fra forskellige vinkler interesserer sig for det 'kvindehav', der er en passende betegnelse for adskillige lægmandsreligiøse fænomener i både katolsk og protestantisk kristendom i 1800- og 1900-tallet. Ordet er den svenske skønlitterære forfatter Per Olov Engquists (1934-). Han benytter sig af det i fremstillingen af et svensk pinsemenighedsmiljø i sin roman Lewis rejse (2001, 10. 92-122). Men samtidsbeskrivelser af N.F.S. Grundtvigs (1783-1872) forsamlinger i Vartov kirke 1839-1872 kunne være realhistoriske kilder til den tendens, som Linda Woodhead har stillet akademisk skarpt på, nemlig at kvinder i det 19. og 20. århundrede førte an i fromhedsliv og kirkegang (Woodhead 2004, 248-251). 
i hvert fald anvendes de som velsignelsesredskaber. Det er da også dette redskab, som forårsager Maries helbredelse:

Pludselig, netop som Monstransen bares forbi, og hun [Marie] betragtede den med flammende Øjne, var det, som blændedes hun af en Lynstraale [...] Hendes jomfruelige Legeme gennembævedes af voldsomme Rystelser, som om en gaadefuld Kraft genfødte det fra Taa til Top (ibid., 550-551).22

Dette citat er interessant af flere årsager. Først og fremmest fordi det skildrer romanens narrative hovedbegivenhed. Men også fordi det bestemmer de kræfter, der er på spil under nadverprocessionen, som lynende energi. Den relevante pyrodynamiske term i denne sammenhæng bør derfor være 'elektrisk', hvorfor det ikke virker overraskende, at Marie opfører sig som om hun har fået et voldsomt stød og ryster. Hendes helbredelse er spontan og komplet; hun afviger fra de almindeligvis gradvise helbredsforbedringer og overbeviser øjeblikkeligt Det Medicinske Bureau, hvis kontor hun opsøger umiddelbart efter hændelsen (ibid., 553-561). I forsøg på at opsummere den ovenstående gennemgang, bringer jeg her følgende skema:

\begin{tabular}{|c|c|c|}
\hline & Fakkeloptog & Nadverprocession \\
\hline Tidspunkt & Aften & Eftermiddag \\
\hline Deltagere & $\begin{array}{l}\text { - Kvinder } \\
\text { - Anonyme individer } \\
\text { - Lægmænd } \\
\text { - Grimme og simple } \\
\text { - } 30.000\end{array}$ & $\begin{array}{l}\text { - Mænd } \\
\text { - Ordnede grupperinger af læg- } \\
\text { mænd } \\
\text { - Kirkeligt ansatte } \\
\text { - Flotte og pyntede } \\
\text { - } 350-450\end{array}$ \\
\hline Redskaber & En masse kærter & Én monstrans \\
\hline Rute & Cirkel & Linje \\
\hline $\begin{array}{l}\text { Følgets placering i for- } \\
\text { hold til protagonisterne }\end{array}$ & Periferi & Centrum \\
\hline Fare & Diffusion & Implosion \\
\hline Alternativ lokation & Have & Kontor \\
\hline Overnaturlig agent & Jomfru Maria & Jesus \\
\hline Overnaturlig begivenhed & Snigende hierofani & Punktuelt mirakel \\
\hline Overnaturlighed sanses & Olfaktorisk & Visuelt \\
\hline $\begin{array}{l}\text { Dominerende } \\
\text { sindsstemning }\end{array}$ & Ro, hypnotisk tilstand & Ekstase \\
\hline Naturfænomener & $\begin{array}{l}\text { - Kunstigt lyn } \\
\text { - Kunstig morgenrøde }\end{array}$ & $\begin{array}{l}\text { - Lynstråle } \\
\text { - Aftenrøde }\end{array}$ \\
\hline Pyrometaforik & Vandig analogi & Elektrisk orientering \\
\hline
\end{tabular}

Figur 1. Strukturelle forskelle mellem fakkeloptog og nadverprocession i Zolas Valfartsstedet (1894)

22 På dette punkt holder jeg bristefærdig en vulgær-freudiansk analyse tilbage. Denne ville have holdepunkter som lune grotter og store monstranser. Men en sådan udlægning ville være upassende af flere grunde. En af de oplagte er, at jeg ikke har kunne finde tilstrækkeligt belæg for, at Zola faktisk havde læst Sigmund Freud, hvis første publikationer er fra begyndelsen af 1890'erne, skønt en enkelt nyere forskningsudgivelse foreslår et kendskab (White 2011). 
På dette sted i redegørelsen finder jeg det nødvendigt at tilføje et par afklarende terminologiske overvejelser: I det foregående har jeg anvendt ordene procession, optog og følge som synonyme begreber, ligesom jeg har behandlet de to begivenheder, beskrevet i Zolas Valfartsstedet, som varianter af den samme overkategori. Herved ligger et implicit alternativ til et moment i Ronald L. Grimes processionsdefinition, som tillægger ruten stor betydning. Kun lineære bevægelser fra punkt a til b og såkaldt bi-lineære fra punkt a til b og tilbage til a godtages som 'rigtige' processioner. Cirkambulære bevægelser falder således uden for hans bestemmelse, fordi "[p]rocessual action is not movement around a sacred object but to a special place" (1987, 7416; original kursivering). Følger man denne opdeling, ville Zolas fakkeloptog med andre ord ikke kunne opfattes som en processionsbeskrivelse. Men også nadverprocessionen bryder med Grimes' skematisering på et vist punkt. I kraft af den eksalterede folkemængde bevæger denne begivenhed sig væk fra handlingsgenren procession og i retning af 'paraden': "The solemn or meditative tone of a procession differentiates it from the expansive celebrative ethos of a parade" (ibid., 7417). Sådanne afgrænsninger er muligvis nødvendige, når man ønsker at uddestillere en idealtypisk stabilitet på baggrund af et stort empirisk materiale. Det er imidlertid ikke et gunstigt afsæt for arbejdet med specifikke fænomener. I hvert fald ikke, hvis man ønsker at foretage mere end skolastiske vurderinger af, om man må benytte processionsprædikatet om fænomen x og y eller ej. Derfor går jeg pragmatisk til værks og behandler fakkeloptoget og nadverprocessionen som instantiationer af samme handlingsart. Denne fremgangsmåde finder ikke mindst sin begrundelse i Zolas overlagte modbilleddannelse mellem de to begivenheder, som bliver tydelig af de strukturelt-systematiske forskelle og som taler for, at de er tænkt som en art 'tese og antitese' inden for det samme domæne. Som vi skal se i det følgende afsnit er denne forskelsdannelse endvidere med til at tydeliggøre den positive vurdering af processionerne som ritualer; denne vurdering er netop det, der binder beskrivelserne af ritualerne sammen. Endvidere er denne positive vurdering vigtig for romanen samlet betragtet: Den er nemlig et afvigende, påfaldende og ambivalent træk, fordi Zola i romanen ellers forholder sig utvetydigt negativt til religiøse forestillinger og praksisformer.

\section{Kraft og virkning i de to processioner}

I begge processioner lader Zola hovedparten af deltagerne være af den opfattelse, at der er overnaturlige kræfter på spil. I tillæg til at hensætte Marie i en henrykt døs udtrykker virkningen af disse kræfter i den første procession sig som en uhåndgribelig, højtidelig stemning knyttet til en fornemmelse af, at kvindernes inderlige deltagelse skaber en forbindelse til tidligere tiders oprigtige fromhedsliv, hvilket får den ellers skeptiske Pierre til at glædes over, at Lourdes hermed "atter var Helligdommens By, Miraklernes Sted" (ibid., 411). Nadverprocessionens virkning er omvendt målbar og håndfast. Også i dette tilfælde anerkender Zolas tvivlende Pierre 
ritualets effikacitet - den kan han ikke "lukke sine Øjne for" (ibid., 541). Han forsøger at forklare, hvad det er "for en ukendt Magt," der sætter "denne Mængde i Stemning" og frembringer helbredelserne; "thi de [...er] Kendsgærninger" (ibid.). I de følgende overvejelser poder Zola Pierres tanker med troper velkendt i intellektuelle miljøer i fin de siècle-Frankrig. Man hører et ekko af den udbredte interesse for de voldsomme kræfter, der gemmer sig i store menneskemængder, som var karakteristisk for fransk refleksion i en periode, der kun lå på omtrent 100 års afstand af erfaringerne fra den franske revolution. Denne interesse fortættede sig til det vidensfelt, der blev kendt som massepsykologien og som havde Gustave Le Bon (1841-1931), forfatter til bøger med titler som Psychologie des Foules (1895) og La Révolution Francaise et la Psychologie des Revolutions (1912), som frontfigur. ${ }^{23}$ Inden for den medicinske forskning interesserede man sig i forlængelse heraf for manipulation af enkeltindivider. 'Hypnose' og 'suggestion' var således modeord i årene omkring det 20. århundredeskifte. Google Books Ngram Viewer viser eksempelvis, at ordenes frekvens stiger voldsomt først i 1880'erne og bider sig fast i perioden op til år 1900. ${ }^{24}$ 'Hystérie' følger den samme udvikling, ${ }^{25}$ hvilket giver anledning til at anføre, at især kvinder blev anset som letpåvirkelige. Hysteri var, som jeg allerede har strejfet, nemlig en psykosomatisk diagnose forbeholdt kvinder. Psykiateren Jean-Martin Charcot (1825-1893), der var førende på feltet, udførte da også først og fremmest undersøgelser og forsøg på kvinder (Goldstein 1982). Disse mentale knudepunkter antyder, at dette var en tid optaget af indbildte tilstande og social-psykologiske kræfter. I den forstand er Zola og Valfartsstedets Pierre børn af deres tid. Dette bliver særlig tydeligt i de overvejelser, der fortsætter den tankerække, jeg afbrød ovenfor: Den alvidende fortæller giver således stemme til Pierres konstatering af, at helbredelserne må tages alvorligt, for her er noget virkeligt på spil, "som ingen Fysiolog endnu [... har] studeret!" (Zola 1894, 541). Måske er forklaringen, at “en Mængde bliver til et Individ, der overfor sig selv tusindfold kan forstærke sin Suggestionsævne?"(ibid.). Mon “denne Mængde under ganske særegne Omstændigheder kunde tvinge Stoffet til Lydighed?" (ibid.). En sådan model ville kunne forklare, hvorfor "de mest ophidsede Individer i denne Mængde netop var dem, der hyppigst helbrededes" (ibid.). Muligvis forholdt det sådan, at begejstringens "Ild samledes og koncentreredes, og den Magt, der virkede, var en Trøstens, Haabets, Livets Magt" (ibid.)? Disse spørgsmål stiller Pierre sig selv og underkender det overnaturlige som forklaringsmulighed.

Den pointe, jeg nærmer mig, er, at de kræfter, som er på spil i disse to processioner, nogenlunde synes at svare til det grundlæggende modsætningsforhold mellem

23 Men en lang række tænkere før eller samtidig med Le Bon havde forsøgt at afdække de fysiske forsamlingers afgørende betydning for samfundsforståelsen og for forståelsen af det enkelte individ. Gabriel Tarde (1843-1904) og Hippolyte Taine (1828-1893) er nogle få, men oplagte eksempler, skønt man som J.S. McClelland (2010) med rette kan være af den opfattelse, at vi skal uden for Frankrig og tilbage til Platon for at finde det idehistoriske begyndelsespunkt for sådanne overvejelser.

24 Søgning foretaget på https://books.google.com/ngrams.

25 Søgning foretaget på https://books.google.com/ngrams. 
'rolige' og 'eksalterede' ritualer, som religionsforskere til forskellige tider og fra forskellige indfaldsvinkler har forsøgt at indfange årsagerne til eller principperne for. Det seneste forsøg er foretaget af Harvey Whitehouse i hans kontrastering af de såkaldt doktrinære og imagistiske religiøsitetsmodi formuleret i Modes of Religiosity. A Cognitive Theory of Religious Transmission (2004). Men også Max Webers klassiske modstilling mellem rutiniserede og karismatiske religionsformer er et oplagt eksempel på en sådan modstilling. En anden klassiker i denne sammenhæng er Ruth Benedicts nietzscheanske begrebspar apollinske og dionysiske religiøse udtryksformer præsenteret i Patterns of Culture (1935). Mange accentforskydninger til trods synes der at være en vis enighed om, at 'rolige' ritualer er konservative i den forstand, at de ofte vil rette sig mod vedligeholdelsen af visse religiøse forestillinger og den pågældende institutions historiske selvforståelse. Omvendt synes der at være nogen grad af enighed om, at de 'eksalterede' ritualer typisk tjener til at styrke enkeltindividers religiøse identitet og konkrete gruppers fællesskabsfølelse gennem voldsomme oplevelser. Jeg mener, at denne dynamik kan spores i Zolas processionsbeskrivelser i Valfartsstedet: Den rolige, grænsende til hypnotisk-søvndyssende, rituelle aftenbegivenhed synes at styrke det kollektive forestillingsunivers bygget op omkring den hellige jomfru, ligesom den synes at etablere en tidslig forbindelse mellem folkefromheden i de moderne 1890'ere og en middelalderlig pietet, som fortællerstemmen og Pierre vurderer er det moderne udtryks autentiske forlæg. Den eksalterede nadverprocession beskriver omvendt en enkeltstående, voldsom følelsesmæssig påvirkning og fysisk forandring, som får afgørende betydning for Marie og som gør stærkt indtryk på resten af forsamlingen, der opfatter det som en mirakuløs begivenhed.

De ord, Zola gør brug af til at beskrive denne dynamik (hypnose, ekstase, suggestion osv.), henter han fra samtidsvokabularet $i$ anvendelse blandt psykiatere og psykologer. Opfattelsen, som disse termer var ladet med, at kollektive begivenheder kan udløse skjulte, sociale kræfter, var imidlertid særdeles afgørende inden for endnu en faggruppe: (religions)sociologer som Émile Durkheim (1858-1917), Henri Hubert (1872-1927) og Marcel Mauss (1872-1950). Durkheims begreber for sådanne kræfter var to tredjeordens-, etic-konstruktioner: Den første er 'kollektiv effervescence' - om følelsesmæssige opbrusninger, der kan finde sted under kollektive ritualer og som typisk involverer rytmisk koordinering fx under dans eller sang. Durkheim beskriver i øvrigt ofte denne mekanisme i elektriske termer, som nærmer sig Zolas (jf. Durkheim 1995 [1912], 216-221). Den anden er 'dynamogénique' om den gunstige, identitetsopbyggelige virkning religiøse forestillinger og praksisformer øver på enkeltindivider (jf. Durkheim 2014 [1914]). ${ }^{26}$ Hubert og Mauss transformerede Robert Codringtons emic-beskrivelse af melanesiske kraftforestillinger kondenseret i mana-begrebet (Codrington 1891) til en almen etic-kategori, der rummer forestillinger om visse genstandes, personers og handlingers kraft eller 'magiske potentiale' (jf. Tybjerg 2007, 170; Sørensen, under udgivelse). Hvor de baserer deres sociologiske teoridannelser på antropologiske feltrapporter fjernhøstet i

26 Jeg takker Tove Tybjerg for oplysende og afklarende korrespondance om dette vigtige begreb. 
Melanesien og Australien, koncentrerer Zola sin ambivalente, skønlitterære polemik om en lokal folkereligiøs praksis, der både var blomstrende og særdeles kontroversiel. Jeg foreslår, at Zolas skandaløse roman og Lourdes som fænomen, hvoraf processionsritualerne var iøjnefaldende elementer, må medregnes som en del af den kontekst, der gjorde det akut relevant for Durkheim, Mauss og Hubert at udvikle deres teorier om religion og kollektiv kraft.

Zola skrev en fortælling, hvori ritualers positive kraftpotentiale fremstår som indlysende og afgørende. Dette fremgår af hans gennemgang af de to grundlæggende rituelle udtryksformer, som processionerne repræsenterer: Den første genererer social sammenhængskraft og rodfæster deltagerne i en dyb historisk tradition, som sikrer en kulturel og eksistentiel 'meningsfylde'; den anden sørger for en individuel fysisk og mental revitalisering. Men samtidig understreger Zola igen og igen, at disse positive virkninger trænger til en videnskabelig forklaring, fordi det religiøse værensmodus har overskredet sidste holdbarhedsdato: Aktiviteten i Lourdes er et desperat "Forsøg paa at vække Miedelalderens [sic!] klippefaste Tro" (Zola 1894, 765). Desperat fordi: "Historien gaar ikke tilbage... Menneskene vender ikke om og bliver til Børn...27 Tiderne er anderledes, altfor megen ny Sæd er udstrøet og har spiret, ${ }^{28}$ til at Nutidsmennesket kan tænke som han tænkte for Aarhundreder siden" (ibid., 765-766). Det pyrenæiske landskab er med andre ord locus for "den gamle katholske Trosforms Dødskamp" (ibid., 766), konkluderer Pierre formodentligt indforstået med Friedrich Nietzsches 'Gud-er-død'-slagord. Men de positive, sociale kræfter indlejret i de religiøse udtryksformer bør oversættes til nye, gangbare, opbyggelige forestillinger og praksisser - det vil sige til "en ny Religion!" (ibid., 775). En sådan er imidlertid "ikke let at opfinde; han [Pierre] vidste ikke, hvordan der skulle dannes en Overgang fra den gamle døde Tro til den ny, der endnu ikke var født" (ibid., 775-776).

Her er endnu et punkt, der knytter Zola og Durkheim sammen. Jeg nævner foregribende og parentetisk, at min interesse for dette sammenfald skærpes af Wolf Lepines' overbevisende fremvisning af (særligt de naturalistiske strømninger i) skønlitteraturen og sociologien som konkurrerende vidensdiskurser i årtierne omkring år 1900 i Frankrig $(2006,49-102)$. Begge bestræbte sig på gennem stadig nye metoder at forklare og fortolke 'den sociale virkelighed'. Zola og Durkheim er afgørende repræsentanter for hver sin diskurs. Og i Les formes élémentaires de la vie religieuse formulerer sociologen sig forbløffende parallelt til naturalisten:

Hvis vi i dag finder det svært at forestille os fremtidens fester og ceremonier, skyldes det, at vi befinder os i en overgangsperiode kendetegnet ved moralsk middelmådighed. Fortidens store ting, som begejstrede vore forfædre, kan ikke længere vække vores iver, enten fordi de er gledet så aldeles ind i den fælles sædvane, at vi ikke længere kan få øje på dem, eller også fordi de ikke længere passer til vores forhåbninger. I mellemtiden er der ikke fundet nogen erstatning for dem. Vi bliver ikke længere 'elektrifi-

27 Denne sammenkædning af ontogenetisk og fylogenetisk udvikling er naturligvis endnu et tidstypisk kendetegn ved Zolas fremstilling.

28 Det er her næppe helt tilfældigt, at Pierre hedder Froment ('hvede') til efternavn, ligesom Maries 'Guersaint' lægger sig (lidt for) sigende tæt op ad 'hellig krig'. 
cerede' af de principper i hvis navn kristendommens forestillinger om menneskelig lighed og broderskab synes at give for stort spillerum til uretfærdige uligheder. Dens [kristendommens] medlidenhed med de svage fremtræder for platonisk for os. Vi kunne ønske os én, der var mere energisk, men kan endnu ikke tydeligt se, hvad den bør være eller hvordan den faktisk ville kunne realiseres.

Med andre ord, de tidligere guder er aldrende eller døende og andre er endnu ikke født $(1912,610-611) .{ }^{29}$

Den videnskabelige forklaring på de religiøse kræfter, som Zola efterspurgte, mente Durkheim at levere. Religiøse kræfter er basale, gruppe-dynamiske kræfter, lyder omkvædet i hans opus magnum. Logikken hos både Durkheim og Zola er, at Frankrig efter den franske revolution har befundet sig i et mentalt-kulturelt dødvande, hvor kun survivals som eksempelvis fænomenet Lourdes kan samle og begejstre folk. Begejstringen er reel; men genstanden er krampagtig, anakronistisk og kunstig som væksterne på valfartsstedet, der under fakkeloptoget oplyses fra neden og fremstår med "skinnende grønne Farver ligesom malede Kulissetræer" (Zola 1894, 395).

\section{Konklusion: Processioner som potente 'survivals'}

Den fornemmelse, som Zola indgyder i sin bog, at Lourdes' popularitet udelukkende var en midlertidig kulturel spasme, viste sig ikke at være rigtig. I dag er det et internationalt foretagende med flere årlige besøgende og processioner end nogensinde i hvert fald hvis man kan stole på helligstedets egne rapporter. ${ }^{30}$ En af forklaringerne på denne succes skal måske netop findes i den processionspraksis, som Zola selv var optaget af at skildre. For til trods for, at der i $1890^{\prime}$ erne var tale om et stadig relativt nyt helligsted, indførtes processionstraditionen tidligt efter Bernadette Soubrious påståede visioner af jomfru Maria på en sådan måde, at deltagere følte sig forbundet med en 'autentisk, middelalderlig religionsdyrkelse'. Dette er i hvert fald de konklusioner, man med Ruth Harris' hjælp kan drage på baggrund af den store mængde samtidigt kildemateriale, der både rummer lægmands- og klerikale beretninger $(1999,254)$. Og det er den fornemmelse, Émile Zola giver Pierre Froment. I dette perspektiv kan denne case - som altså både indeholder de historiske omstændigheder vedrørende fremvæksten af helligstedet og den intellektuelle fordøjelse af denne fremvækst - være med til at understøtte Roy Rappaports teori om, at ritualer, der lykkes med at overbevise sine deltagere om, at praksissens etablering fortaber sig i en fortidståge, vil have lettere ved at opnå opbakning (1999, 32-33). Denne case kan endvidere bruges som et eksempel på, at denne fortidståge i 1800tallets romantiske Europa med fordel strakte sig tilbage til middelalderen. Derfor kan denne case endelig være med til at komplicere den betragtning, som Ronald L.

29 Dette er min oversættelse af passagen, som kan tilgås på https://archive.org; i Karen Fields glimrende engelske oversættelse fra 1995: s. 429.

30 Som kan findes på Sanctuaire de Notre-Dame de Lourdes' hjemmeside: http://en.lourdesfrance.org/ 
Grimes gør sig til talsmand for: at $\mathrm{i}$ "industrial cultures, processions are likely to decline in frequency or significance and thereafter function only as minor gestural tribularies to other rituals" (1987, 7416). Et gennemgående træk i det mangeartede materiale, der knytter sig til Lourdes, synes nemlig at være forsøget på at genoplive en simpel og autentisk landsby-religiøsitet foretaget af nostalgiske moderne, industrialiserede storbykulturelle massemennesker. Man kunne foreslå, at de er tiltrukket af stedet netop på grund af det, Zola tænkte på som en 'forældet' karakter; at de deltager i processionerne, som er potente netop fordi de er 'survivals'.

\section{LITTERATUR}

Baunvig, Katrine Frøkjær

2014 “Durkheim og 'Religionens fremtid': En oversættelse af en tale af Émile Durkheim med indledning", Religionsvidenskabeligt Tidsskrift 61, 108-122.

Bellah, Robert N.

1964 "Religious Evolution", American Sociological Review 29 (3), 358-374. https://doi.org/10.2307/2091480

2011 Religion in Human Evolution. From the Paleolithic to the Axial Age, Cambridge, Massachusetts: The Belknap Press of Harvard University Press. https://doi.org/10.4159/harvard.9780674063099

Benedict, Ruth

2005 Patterns of Culture, Florida: First Mariner Books (1934).

Blackboun, David

1994 Marpingen. Apparitions of the Virgin Mary in Nineteenth-Century Germany, London: Alfred A. Knopf.

Burke, Peter

2008 What is Cultural History?, London: Polity.

Bynum, Caroline

2011 Christian Materiality. An Essay on Religion in Late Medieval Europe, Massachussetts: Zone Books. Chateaubriand, F.-R.

1828 Génie du Christianisme, Paris: Garnier Frères (1802). https://fr.wikisource.org/wiki/G\%C3\%A9nie_du_christianisme

Codrington, R.H.

1891 The Melanesians. Studies in their Anthropology and Folk-Lore, London: Clarendon. https://archive.org/details/melanesiansstudi00codruoft

Douglas, Mary

1966 Purity and Danger, London: Routledge. https://doi.org/10.4324/9780203361832

Durkheim, Emile

1994 Les formes élémentaires de la vie religieuse. Le systemè totémique en Australie, Paris: Quadrige/PUF (1912).

Engquist, Per Olov

2001 Lewis Rejse, København: Samleren.

Goldstein, Jan

1982 "The Hysteria Diagnosis and the Politics of Anti-Clericalism in Nineteenth-Century France", Journal of Modern History 54, 209-239. https://doi.org/10.1086/244132

Granziera, Patrizia

2004 "From Coatlicue to Guadalupe: The Image of the great Mother in Mexico", World Christianity, 250-273. 
Grimes, Ronald L

2005 “Procession (1987)", in: Lindsay Jones, ed., Encyclopedia of Religion, 2. ed., Detroit: Macmillan Reference, 7416-7418.

Harris, Ruth

1999 Lourdes. Body and Spirit in the Secular Age, London: Penguin Books.

Huysmans, Joris-Karl

1925 The Crowds of Lourdes, London: Burns Oates \& Washbourne.

Kaufmann, Suzanne K.

2005 Consuming Visions. Mass Culture and the Lourdes Shrine, Cornell: Cornell University Press.

Lang, Bernhard

2015 "Processions", in: Hans Dieter Betz et al., eds., Religions Past and Present, Leiden: Brill. http://doi.org/10.1163/1877-5888_rpp_COM_024492

Lassere, Henri

1906 Our Lady of Lourdes, London: Kenedy \& Sons, 1906. Tilgås:

https://archive.org/details/ourladyoflourdes00lassiala

Lepines, Wolf

2006 Die drei Kulturen. Soziologie zwischen Literatur und Wissenschaft, Berlin: Fischer.

Logan, Peter Melville

1997 Nerves and Narratives: A Cultural History of Hysteria in 19th-Century British Prose, Berkeley: University of California Press. http://ark.cdlib.org/ark:/13030/ft5d5nb38x/

Lundager Jensen, Hans J.

2016 "Maria Magdalene i Provence. Tribal og post-aksial askese", Religionsvidenskabeligt Tidsskrift 64, 96-120.

Maunder, Chris

2016 Our Lady of the Nations. Apparitions of Mary in 20 th -Century Catholic Europe, London: Oxford University Press. https://doi.org/10.1093/acprof:oso/9780198718383.001.0001

McClelland, J.S.

2010 The Crowd and the Mob. From Plato to Canetti, London: Taylor \& Francis.

Moretti, Franco

2014 The Bourgois. Between History and Literature, London: Verso.

Osterhammel, Jürgen

2009 The Transformation of the World. A Global History of the Nineteenth Century, Princeton: Princeton University Press.

Rappaport, Roy A.

1999 Ritual and Religion in the Making of Humanity, Cambridge: Cambridge University Press. https://doi.org/10.1017/CBO9780511814686

Schom, Alan

2015 Émile Zola. A Bourgois Rebel, London: Endeavour Press.

Seales, Chad. E

2008 "Parades and Processions: Protestant and Catholic Ritual Performances in a Nuevo New South Town", Numen 55 (1), 44-67. https://doi.org/10.1163/156852708X271297

Sinding Jensen, Jeppe

2003 The Study of Religion in a New Key: Theoretical and Philosophical Soundings in the Comparative and General Study of Religion, Aarhus: Aarhus Universitetsforlag.

Sørensen, Jesper

- $\quad$ "Force and Categorization: Reflections on Marcel Mauss and Henri Hubert's Equisse d'une théorie générale de la magie", under udgivelse.

Thomsen, Mads Rosendahl

2013 “Meget fjern læsning. Litteraturen, de store data og Google Ngrams", Passage 70, 133-146. 
https://doi.org/10.7146/pas.v28i70.24490

Thomsen, Søren Ulrik

2005 "Pro ecclesia", Kritik af den negative opbyggelighed, København: Vindrose.

Tybjerg, Tove

2007 "Reflections on 'Charisma'”, Nordic Journal of Religion and Society 20 (2), 167-178.

Van Osselaer, Tine

2014 "Introduction", in: Tine van Osselaer \& Patrick Pasture, eds., Christian Homes. Religion, Family, and Domesticity in the 19th and 20th Centuries, Leuven: Leuven University Press.

Warner, Marina

2003 Alone of all her Sex: The Myth and the Cult of the Virgin Mary, London: Oxford University Press.

Weber, Eugen

1976 Peasants into Frenchmen. The Modernization of Rural France, 1870-1914, Palo Alto: Stanford University Press.

White, Claire

2011 "Zola and Freud: Spent Energy in Therese Raquin", The Romantic Review 102, 349-368.

Whitehouse, Harvey

2004 Modes of Religiosity. A Cognitive Theory of Religious Transmission, Maryland: Altamira Press.

Woodhead, Linda

2004 An Introduction to Christianity, Cambridge: Cambridge University Press.

https://doi.org/10.1017/CBO9780511800863

Ziolkowski, Theodore

1990 German Romanticism and Its Institutions, New Jersey: Princeton University Press.

Zola, Émile

1894 Valfartsstedet, København: Politiken Trykkeri.

Katrine Frøkjær Baunvig, lektor, ph.d., Religionsstudier, Institut for Historie, Syddansk Universitet baunvig@sdu.dk 